\title{
Serum C-Reactive Protein and Diabetic Retinopathy
}

\author{
Waled Mahdy Nada', Doaa Attia Abdel-Moety² \\ ${ }^{1}$ Ophthalmology Department, Faculty of Medicine, Zagazig University, Zagazig, Egypt \\ ${ }^{2}$ Physiology Department, Faculty of Medicine, Zagazig University, Zagazig, Egypt \\ Email: walednada_69@hotmail.com
}

How to cite this paper: Nada, W.M. and Abdel-Moety, D.A. (2017) Serum C-Reactive Protein and Diabetic Retinopathy. Open Journal of Ophthalmology, 7, 73-78. https://doi.org/10.4236/ojoph.2017.72011

Received: February 3, 2017

Accepted: April 12, 2017

Published: April 14, 2017

Copyright (c) 2017 by authors and Scientific Research Publishing Inc. This work is licensed under the Creative Commons Attribution International License (CC BY 4.0).

http://creativecommons.org/licenses/by/4.0/

\begin{abstract}
Purpose: To study the role of C-reactive protein (CRP) in the progression of diabetic retinopathy before and after treatment to determine if it can be used as a biomarker for progression or regression. Methods: This observational case study included 90 persons divided into 4 groups: group A of 30 normal persons (non diabetic) as a control group, group B of 30 diabetic patients without retinopathy, group $\mathrm{C}$ of 30 untreated patients with proliferative diabetic retinopathy (PDR) and group D of the same patients of group $\mathrm{C}$ after 3 months of laser treatment by pan retinal photocoagulation (PRP). Serum CRP protein was measured in all groups, interpretation of results was applied. Results: The study revealed that serum CRP level increased significantly in patients with PDR (group C) in comparison to both groups of normal control persons (group A) and diabetic patients without retinopathy (group B) $(\mathrm{P}<$ 0.001 ), and slightly decreased but insignificantly after three months of laser treatment by PRP (group D) $(\mathrm{P}>0.05)$. Also the same finding was noticed in elderly patients above 50 years. Conclusion: CRP is considered a biomarker for PDR even in older age patients, but not a good indictor used for follow up patients after treatment.
\end{abstract}

\section{Keywords}

C-Reactive Protein, Proliferative Diabetic Retinopathy, Pan Retinal Photocoagulation

\section{Introduction}

One of the most important causes of blindness in many countries is diabetic retinopathy (DR). Due to ischemic retinal changes, the patients may progress into proliferative diabetic retinopathy (PDR) including retinal neovascularization, vitreous hemorrhage ending by tractional retinal detachment and neovascular 
glaucoma and hence loss of vision. Pan retinal photocoagulation (PRP) and intravitreal injection of anti-vascular endothelial growth factor (anti-VEGF) are considered mandatory treatment modalities in PDR [1] [2].

The process of progression of diabetic retinopathy may depend on different mechanisms including long duration of diabetes, prolonged hyperglycemia, microangiopathic changes, abnormal metabolic pathway, oxidative stress and subclinical inflammation. Early detection of PDR and follow up of patients by serum biomarkers beside the clinical picture may play a role in prevention and control of PDR [3] [4].

In 1930, C-reactive protein (CRP) was identified, it is a protein synthesized mainly by liver and adipose tissue, it is considered as acute phase protein increased in inflammatory and microbial invasion. In practice measurement of CRP is helpful in diagnosis of some inflammatory conditions. The role of CRP in DR is still not clear, but many studies reported that CRP increased in DR especially in PDR depending on the inflammatory process and abnormal metabolic and vascular pathways mechanisms involved in DR giving the importance for CRP in assessment of the DR state [5] [6] [7]. Also aging process and hyperglycemia activate multiple cellular pathways that play the important role in progression of diabetic retinopathy in a relation to the inflammation and endothelial injury that associated with the pathogenesis of diabetic microvascular complications [8] [9] [10].

Some studies as Song et al. (2015) [11], Yang et al. (2016) [12] and Zhou et al. (2016) [13] reported the relationship between elevated serum CRP and the progression of proliferative changes of diabetic retinopathy, they also stated that CRP not significantly increased in NPDR, but significantly increased in PDR, so that CRP is as considered a biomarker in the progression into PDR.

This study was limited in evaluation of serum CRP in cases with DR without attention to other contributing factors that may play a role in the progression of DR.

\section{Patients and Methods}

This observational case control study was performed in Zagazig University Hospitals in the period from January 2016 to September 2016. The study was performed according to WMA Declaration of Helsinki-Ethical Principles for Medical Research Involving Human Subjects.

The study included 90 persons who were selected to be free of any possible contributing factors that may affect serum CRP as inflammatory and degenerative conditions. They were divided into 4 groups, the group A of 30 healthy non diabetic persons as a control group, group B of 30 diabetic patients without retinopathy, group $\mathrm{C}$ of 30 patients with untreated bilateral PDR, and group D of the same patients in group $\mathrm{C}$ but after 3 months of laser treatment (PRP).

Criteria of selection of the control group (A): The age of persons was determined according to group $\mathrm{B}, \mathrm{C}$ to be similar matched.

- Age from 30 - 70 years. 
- Non diabetic persons via estimation of fasting blood glucose level below 110 $\mathrm{mg} \%$, postprandial level below $150 \mathrm{mg} \%$ and glycosylated hemoglobin (HbA1c) below $6 \%$.

- Free of other degenerative or inflammatory systemic or ophthalmic diseases by systemic and ophthalmic examination.

Criteria of selection of group B:

- The same criteria in the control group A except they are diabetic patients (both type I and II) under medical treatment without retinopathy to detect normal retinal finding by indirect ophthalmoscope, slit-lamp biomicroscopy and fluorescein angiography.

Criteria of selection of group C:

- The same criteria in the control group A except they are diabetic patients (both type I and II) under medical treatment with PDR diagnosed by indirect ophthalmoscope, slit-lamp biomicroscopy and florescence angiography by detection of neovascular malformations at optic disc (NVD), elsewhere in the retina (NVE) or at iris (NVI). Cases with vitreous hemorrhage and tractional retinal detachment were excluded.

Criteria of group D:

- The patients in this group represented the same patients of group C but after 3 months of bilateral laser treatment by PRP, 1000 - 1400 shots of double frequency Yag laser of moderate power, spot size $200-400 \mu \mathrm{m}$, duration 0.1 second.

All groups were subjected to estimation of serum level of C-reactive protein, by collection of fasting 12 hours venous blood samples, estimation of serum (CRP) using C-Reactive Protein ELISA Kit, Human (CYT298) (Merck).

Data was collected and statistical analysis was performed using One Way ANOVA, determination of $\mathrm{P}$ value, $>0.05$ was insignificant, $<0.005$ was significant and $<0.001$ was highly significant.

\section{Results}

The demographic data of the study revealed that in the control group $\mathrm{A}$, there were 16 male (53.3\%) and 14 female (46.7\%), in group B, C there were 15 male (50\%) and 15 female (50\%), The mean age in the control group A was (52.55 \pm $6.28)$, in group $\mathrm{B}$ was $(51.35 \pm 7.06)$ years, in group C, D was $(50.15 \pm 3.59)$ years.

The type of diabetes in group B was type I diabetes in 11 patients (36.6\%) and type II in 19 patients (64.4\%) and in group C, D Type I in 10 patients (33.3\%) and type II in 20 patients (66.6\%).

The level of serum CRP in the control group A was $(8.23 \pm 4.12) \mathrm{mg}-\mathrm{L}$ not differed significantly from group $B$ of diabetic patients without retinopathy ( $7.89 \pm$ 3.02) mg-L ( $P>0.05)$, but differ significantly from group $C$ of patients with untreated PDR $(14.03 \pm 6.19) \mathrm{mg}-\mathrm{L}(\mathrm{P}<0.001)$ and in group $\mathrm{D}(13.9 \pm 4.43) \mathrm{mg}-\mathrm{L}$ which not differed significantly from group $\mathrm{C}(\mathrm{P}>0.05)$ (Table 1$)$.

Also, the level of serum CRP among persons above 50 years old in the control group A was $(11.03 \pm 1.52) \mathrm{mg}$-L not differed significantly from the same age 
Table 1. Demographic data and serum CRP levels in all groups.

\begin{tabular}{|c|c|c|c|c|c|c|}
\hline \multirow{3}{*}{ Parameters } & \multicolumn{4}{|c|}{ Sex } & \multirow{3}{*}{ Mean age } & \multirow{3}{*}{$\begin{array}{c}\text { Serum CRP } \\
\text { Mg-L }\end{array}$} \\
\hline & \multicolumn{2}{|c|}{ Male } & \multicolumn{2}{|c|}{ Female } & & \\
\hline & No. & $\%$ & No. & $\%$ & & \\
\hline Group A & 16 & 53.3 & 14 & 46.7 & $52.55 \pm 6.28$ & $8.23 \pm 4.12^{\star}$ \\
\hline Group B & 15 & 50 & 15 & 50 & $51.35 \pm 7.06$ & $7.89 \pm 3.02^{\star \star}$ \\
\hline Group C & 15 & 50 & 15 & 50 & $53.15 \pm 5.59$ & $14.03 \pm 6.19^{* * *}$ \\
\hline Group D & 15 & 50 & 15 & 50 & $53.15 \pm 5.59$ & $13.9 \pm 4.43^{* * * *}$ \\
\hline
\end{tabular}

$\mathrm{P}(>0.05)$ insignificant between ${ }^{*}$ and ${ }^{* *}$ (group A, B). P $(<0.001)$ highly significant between ${ }^{* *}$ and ${ }^{* *}$ (group B, C). P (>0.05) insignificant between ${ }^{\star * *}$ and ${ }^{\star * * *}$ (group C, D).

Group in group B of diabetic patients without retinopathy $(12.1 \pm 2.17) \mathrm{mg}-\mathrm{L}$ $(\mathrm{P}>0.05)$, but differed significantly from group $\mathrm{C}$ with untreated PDR $(15.12 \pm$ $1.09)$ mg-L $(\mathrm{P}<0.001)$ and group $\mathrm{D}(14.84 \pm 2.52) \mathrm{mg}$ - $\mathrm{L}$ which also not differed significantly from group $\mathrm{C}(\mathrm{P}>0.05)$.

\section{Discussion}

Micro-vascular changes in diabetic patients may complicate into serious conditions such as PDR, the mechanisms of these changes may be related to different pathological factors. Monitoring of these factors may have a role in follow up of these patients. CRP is considered one of the factors that added a famous question about the relation to DR and the possibility to monitor this factor in the progression and regression of that process. The present study asked this question, which was previously studied by Heng et al. (2013) [4] and Song et al. (2015) [11].

The present study reported that CRP was significantly higher in diabetic patients with PDR in comparison to the control persons and diabetic patients without retinopathy, in agree with the study of Song et al. (2015) [11] and Gorska-Ciebiada et al. (2015) [14], denoting that the vascular and inflammatory pathogenesis in diabetic patients giving the risk for diabetic complications especially in elderly patients as CRP normally increases in elderly persons, and the present study also revealed that it was higher in persons above 50 years than others, but also in elderly diabetic patients with PRD was significantly higher than elderly control persons and diabetic patients without retinopathy $(\mathrm{P}<$ 0.001), so that , an explanation was obtained by Kislinger et al. (1999) [15] and Wautier et al. (2001) [16] who stated that hyperglycemia may be responsible for a change in the immune inflammatory pathway and hence the production of non-enzymatic glycation on lysine and arginine residues accumulate in diabetic tissues-plays the important role in pathogenesis of diabetic complications.

As regards to the serum level of CRP after the laser treatment by PRP, the present study stated that there was no significant difference between the level of CRP in patients with PDR before and after treatment denoting that it not be the important biomarker for follow up of patients after treatment. Also the mechanism of regression of level of the inflammatory biomarkers in relation to treat- 
ment may depend on other different factors that were incorporated in the study of Sharma et al. (2015) [17].

\section{Conclusion}

C-reactive protein was considered a biomarker for PDR, but not a good indictor used for follow up patients after laser treatment. Regular estimation of serum level of CRP especially in elderly diabetic patients may be a good biomarker for diabetic micro-vascular complications. More studies are needed for evaluation of other inflammatory markers that may be contributed in the progression of DR.

\section{Conflict of Interest}

The authors declare no conflict of interest.

\section{References}

[1] Antonetti, D.A., Klein, R. and Gardner, T.W. (2012) Mechanisms of Disease Diabetic Retinopathy. New England Journal of Medicine, 366, 1227-1239.

https://doi.org/10.1056/NEJMra1005073

[2] Yau, J.W., Rogers, S.L., Kawasaki, R., Lamoureux, E.L., Kowalski, J.W., Bek, T., Chen, S.J., Dekker, J.M., Fletcher, A., Grauslund, J., Haffner, S., Hamman, R.F., Ikram, M.K., Kayama, T., Klein, B.E., Klein, R., Krishnaiah, S., Mayurasakorn, K., O'Hare, J.P., Orchard, T.J., Porta, M., Rema, M., Roy, M.S., Sharma, T., Shaw, J., Taylor, H., Tielsch, J.M., Varma, R., Wang, J.J., Wang, N., West, S., Xu, L., Yasuda, M., Zhang, X., Mitchell, P., Wong, T.Y. and Meta-Analysis for Eye Disease (META-EYE) Study Group (2012) Global Prevalence and Major Risk Factors of Diabetic Retinopathy. Diabetes Care, 35, 556-564.https://doi.org/10.2337/dc11-1909

[3] Tang, J. and Kern, T.S. (2011) Inflammation in Diabetic Retinopathy. Progress in Retinal and Eye Research, 30, 343-358. https://doi.org/10.1016/j.preteyeres.2011.05.002

[4] Heng, L.Z., Comyn, O., Peto, T., Tadros, C., Ng, E., Sivaprasad, S. and Hykin, P.G. (2013) Diabetic Retinopathy: Pathogenesis, Clinical Grading, Management and Future Developments. Diabetic Medicine, 30, 640-650.

https://doi.org/10.1111/dme.12089

[5] Genest, J. (2010) C-Reactive Protein: Risk Factor, Biomarker and/or Therapeutic Target. Canadian Journal of Cardiology, 26, 41-44. https://doi.org/10.1016/S0828-282X(10)71061-8

[6] Budak, Y.U., Akdogan, M. and Huysal, K. (2013) Relationship of PON1 Activity and hsCRP Concentration with Disease Status in Patients with Type 2 Diabetes Mellitus with and without Retinopathy. International Journal of Diabetes in Developing Countries, 33, 40-45. https://doi.org/10.1007/s13410-012-0103-1

[7] Wang, X.L., Dai, Y. and Chen, X.H. (2010) Changes of the Concentration of Serum Adiponectin and High Sensitivity C-Reactive Protein in Type 2 Diabetes Mellitus Patients with Retinopathy. International Journal of Ophthalmology, 10, 1699-1701.

[8] Gologorsky, D., Thanos, A. and Vavvas, D. (2012) Therapeutic Interventions against Inflammatory and Angiogenic Mediators in Proliferative Diabetic Retinopathy. Mediators of Inflammation, 2012, Article ID: 629452. https://doi.org/10.1155/2012/629452

[9] Bending, D., Zaccone, P. and Cooke, A. (2012) Inflammation and Type One Diabetes. International Immunology, 24, 339-346. 
https://doi.org/10.1093/intimm/dxs049

[10] Adamis, A.P. (2002) Is Diabetic Retinopathy an Inflammatory Disease. British Journal of Ophthalmology, 86, 363-365. https://doi.org/10.1136/bjo.86.4.363

[11] Song, J., Chen, S., Liu, X., Duan, H., Kong, J. and Li, Z. (2015) Relationship between C-Reactive Protein Level and Diabetic Retinopathy: A Systematic Review and Meta-Analysis. PLoS One, 10, Article ID: e0144406. https://doi.org/10.1371/journal.pone.0144406

[12] Yang, X.F., Deng, Y., Gu, H., Lim, A., Snellingen, T., Liu, X.P., Wang, N.L., Domalpally, A., Danis, R. and Liu, N.P. (2016) C-Reactive Protein and Diabetic Retinopathy in Chinese Patients with Type 2 Diabetes Mellitus. International Journal of Ophthalmology, 9, 111-118.

[13] Zhou, Z.W., Ju, H.X., Sun, M.Z., Fu, Q.P., Chen, H.M., Ji, H.B., Ji, F. and Jiang, D.M. (2016) Serum Fetuin-A Levels Are Independently Correlated with Vascular Endothelial Growth Factor and C-Reactive Protein Concentrations in Type 2 Diabetic Patients with Diabetic Retinopathy. Clinica Chimica Acta, 455, 113-117. https://doi.org/10.1016/j.cca.2016.02.003

[14] Gorska-Ciebiada, M., Saryusz-Wolska, M., Borkowska, A., Ciebiada, M. and Loba, J. (2015) C-Reactive Protein, Advanced Glycation End Products, and Their Receptor in Type 2 Diabetic, Elderly Patients with Mild Cognitive Impairment. Frontiers in Aging Neuroscience, 7, 209. https://doi.org/10.3389/fnagi.2015.00209

[15] Kislinger, T., Fu, C., Huber, B., Qu, W., Taguchi, A., Du, Y.S., Pischetsrieder, M., Stern, D. and Schmidt, A.M. (1999) N(Epsilon)-(Carboxymethyl) Lysine Modifications of Proteins Are Ligands for Rage That Activate Cell Signalling Pathways and Modulate Gene Expression. The Journal of Biological Chemistry, 274, 31740-31749. https://doi.org/10.1074/jbc.274.44.31740

[16] Wautier, M.P., Chappey, O., Corda, S., Stern, D.M., Schmidt, A.M. and Wautier, J.L. (2001) Activation of NADPH Oxidase by AGEs Links Oxidant Stress to Altered Gene Expression via RAGE. American Journal of Physiology, Endocrinology and Metabolism, 280, E685-E694.

[17] Sharma, S., Purohit, S., Sharma, A., Hopkins, D., Steed, L., Bode, B., Anderson, S.W., Caldwell, R. and She, J.X. (2015) Elevated Serum Levels of Soluble TNF Receptors and Adhesion Molecules Are Associated with Diabetic Retinopathy in $\mathrm{Pa}$ tients with Type-1 Diabetes. Mediators of Inflammation, 2015, Article ID: 279393. https://doi.org/10.1155/2015/279393 
Submit or recommend next manuscript to SCIRP and we will provide best service for you:

Accepting pre-submission inquiries through Email, Facebook, LinkedIn, Twitter, etc. A wide selection of journals (inclusive of 9 subjects, more than 200 journals)

Providing 24-hour high-quality service

User-friendly online submission system

Fair and swift peer-review system

Efficient typesetting and proofreading procedure

Display of the result of downloads and visits, as well as the number of cited articles Maximum dissemination of your research work

Submit your manuscript at: http://papersubmission.scirp.org/

Or contact aim@scirp.org 